\title{
Bagaimana Membela Indonesia
}

Shohibul Anshor Siregar

|" ....... korporat asing yang masuk saat ini jauh lebih dahsyat dari segi kekuatan, profesionalitas dan jaringan global dibanding VOC" |

Apakah yang harus kau katakan kelak kepada pembaca sejarah Indonesia, ketika sekitar 5 atau 10 dasawarsa ke depan misalnya, mereka meragukan kepatriotan Indonesia, karena mereka menemukan bahwa seorang ketua parlemen pada zamannya pernah diturunkan dari jabatannya karena dituduh secara sah dan meyakinkan telah menjadi agen perusahaan raksasa multi-nasional yang beroperasi di dalam negerinya? Bayangkan betapa menyedihkannya lagi jika mereka mengetahui data tanpa keraguan bahwa perusahaan raksasa multi-nasional itu sebetulnya jelasjelas berperan menjadi musuh bagi rakyatnya?

Indonesia sama sekali tak akan dapat dibela oleh siapa-siapa jika pada alinea-alinea berikutnya dalam catatan sejarah itu dinukilkan pula dengan begitu jelas bahwa setelah Indonesia, ketika itu, merasa dengan sangat pasti telah menemukan data yang sebetulnya dapat membawa serta-merta ketua parlemen itu, dan sejumlah petinggi Negara lainnya, ke penjara, berdasarkan tuntutan pidana yang tidak multi-tafsir, namun entah mengapa ia pun dimaafkan begitu saja. la sama sekali tak diberhentikan dari tugas-tugasnya sebagai anggota parlemen. la hanya digeser dari posisinya, dengan merampas jabatan prestisius yang dimilikinya di parlemen.

Dengan cara apa pula Indonesia membela diri dalam "peradilan sejarah" kelak, jika ternyata ketua parlemen itu akhirnya direhabilitasi oleh sebuah mekanisme yang sama sekali tak jelas dan tak bermartabat, sehingga seorang penting lainnya yang lebih patut dijuluki sebagai perbonekaan politik Indonesia, yang pernah menggantikan jabatan ketua parleman itu sekejap, akhirnya diturunkan lagi dengan alasan yang sama sekali tak masuk akal? Ketua parlemen itu kembali didudukkan dalam posisinya semula tanpa novum yang seharusnya untuk suatu rehabilitasi hukum mengikuti perubahan haluan politik bagi warga Negara. Sedangkan ketua parlemen yang sempat menggantikannya untuk sementara waktu itu diturunkan, juga tanpa alasan yang jelas, meskipun kepadanya dijanjikan sebuah jabatan lain. Siapa yang mampu membela Indonesia pada kesahihan data sejarah seperti itu kelak?

Catatan-catatan buruk yang melukiskan ketak-bermartabatan seperti itu banyak sekali ditemukan dalam sejarah Indonesia, dan mungkin hanya orang-orang asing yang lebih mampu mendokumentasikannya untuk alasan kejujuran akademik belaka. Susahlah membela Indonesia dalam peradilan sejarah seperti itu yang konon dimerdekakan dengan sebuah konsep besar yang oleh para bapak bangsanya disebut Pancasila.

Memang paradoks telah menjadi catatan besar bagi Indonesia selama ini. Bung Karno konon mampu berkata kepada dunia bahwa Indonesia akan lebih baik jika memadukan di dalam dirinya asa kenasionalan, kekomunisan dan keagamaan segaligus. Bagaimana ufuk-ufuk diametral ideologi seperti itu bisa didamaikan dalam diri seorang pemimpin besar Indonesia dan dengan penuh kesungguhan pula menawarkannya kepada segenap komponen bangsanya? la juga tercatat penuh 
kesungguhan mendeklarasikan dirinya sebagai raja dalam sebuah republik yang baru didirikan dengan cita-cita besar itu (Indonesia). Raja baru di negeri baru itu pun akhirnya dilontarkan, tanpa sebuah peradilan yang bermartabat, dari singgasananya, karena alasan-alasan yang kemudian terbukti membelah bangsa menjadi musuh sesamanya.

Mencaci-maki raja republik (Indonesia) itu adalah menjadi cara baru bagi raja baru untuk mengesahkan dirinya menjadi penguasa. Entah siapa yang kini patut diadili untuk pertumpahan darah yang memakan korban besar waktu itu untuk sebuah suksesi paling misterius. Negara demokrasi bertradisi kerajaan yang diakibatkan kepenjajahan yang begitu parah selama tiga setengah abad membuat dual-economy (firma \& bazzar: Booke-Geertz) menjadi ciri perekonomian. Selama 350 tahun dijajah Belanda, berhukum warisan Belanda, tetapi orang hanya bisa meminjam istilah-itilah hukum Belanda, tanpa mampu menuturkan bahasa itu di antara sesamanya. Jika pun itu patriotik, entah siapalah yang mau mengakui itu.

Negara agraris yang dinyatakan paling subur karena antara lain terletak dalam peta nikmat sebagai penghuni posisi khatulistiwa, tapi paling rajin melakukan impor beras untuk orang miskin (raskin) agar dapat dibagi-bagikan kepada warganya untuk menyambung hidup mereka yang miskin. Negara yang dihuni oleh para petani ternyata tanpa malu-malu mengimpor cangkul. Bagaimana memahami semua persoalan ini? Pembelaan apa yang dapat dilakukan oleh Indonesia?

Land reform adalah sebuah keharusan, kata Nur Ahmad Fadhil Lubis suatu ketika kepada Amien Rais saat peluncuran bukunya "Agenda Mendesak Bangsa Selamatkan Indonesia" (2006). Karena kebijakan pertanahan yang berorientasi kepentingan kapitalis, tanah yang sejatinya memiliki nilai-nilai kesejahteraan dan keadilan sosial berubah menjadi komoditas tertentu. Petani benar-benar mengalami kesulitan mengakses ketahanan hidup mereka.

Pendidikan sebagai investasi tak luput dari perhatian ilmuan ini. Literacy, key to good health and well-being (melek aksara, kunci untuk kesehatan dan kehidupan manusia yang baik), tegasnya. Buta aksara sangat dekat dengan kebodohan dan kemiskinan. Sebegitu pentingkah renegosiasi kontrak karya pertambangan? Pentingnya pilihan untuk menyegerakan langkah renegosiasi kontrak karya pertambangan di Indonesia, tak dapat dielakkan.

Meski dalam ungkapan yang berbeda, tetapi dalam kesempatan mendiskusikan buku "Agenda Mendesak Bangsa Selamatkan Indonesia" pada tahun 2006 yang lalu, John Tafbu ekonom dari USU berkata "How green your valley, how rich your country, but how poor your people".

Ini benar-benar tak masuk akal. Hanya dapat diterangkan oleh satu konsep, yakni slaven folk (bangsa budak), tegas Dharma Indra Siregar dengan begitu tak sabar. Saya hendak berseru kepada dunia, katanya: Ahmadinejad tak boleh sendirian dalam pertarungan martabat dan ideologi ini. Harus lebih banyak kepalan tangan ke udara menyerukan kejujuran, keadilan dan saling menghargai. Ahmadinejad tidak berdiri tegak mewakili dirinya sendiri, rakyat Iran, dan warga muslim dunia. la menyuarakan 
penderitaan terbaru produk kekejaman dunia. Apa yang diperbincangkan Konferensi Asia Afrika di Bandung, pada dasarnya itu jugalah suara Ahmadinejad. Omong kosong tuduhan penyalah-gunaan nuklir itu, tutup Dharma Indra Siregar saat diberi kesempatan berkomentar tentang buku Amien Rais.

Ketika kepadanya diserahi tugas melakukan kajian khusus dari perspektif pendidikan, Syawal Gultom dari Unimed berkata tegas untuk Amien Rais: "Prof Amien Rais, menegaskan harapannya kepada kaum intelektual untuk terus berjibaku merubah iklim politik yang condong pada dirty business menjadi meaningful and useful business. Oleh karena itu, maka patut kita jadikan pegangan bahwa tugas pokok kaum intelektual adalah memegang tingg-tinggi cermin yang jernih, kritis dan obyektif di depan para penguasa yang biasanya dilingkari dengan pendukung-pendukung yang menjilat”.

Ketika tak satu pun yang berubah signifikan dalam sejarah Indonesia, sejarawan Ichwan Azhari berkata lantang "bussiness runs like usual". la meyakinkan audiens bahwa untuk refleksi indonesia masa kini koorporat asing yang masuk saat ini jauh lebih dahsyat dari segi kekuatan, profesionalitas dan jaringan global dibanding VOC.

Tapi elit politik Indonesia yang berkuasa menyerupai apa yang berlangsung di berbagai pusat pertikaian politik Jawa sejak awal abad 17. Jika dulu ada pada institusi Kraton dan raja-raja, mungkin sekarang ada pada partai, istana, institusi militer, konglomerat dan birokrat dari pusat sampai daerah. Ini lebih cocok sebagai sejarah yang berlanjut.

Bagaimana mempertanggungjawabkan semua ini?

Shohibul Anshor Siregar

Naskah ini pertamakali diterbitkan oleh Harian WASPADA, Medan, 28 Nopember 2016, hlm B7 